\title{
Pemanfaatan Jambu Biji Merah Dan Pisang Ambon Terhadap Peningkatan Kadar Haemoglobin Ibu Hamil
}

\author{
Atik Purwandari ${ }^{1}{ }^{\text {Freike Lumy }}{ }^{2}$,Anggreani Dalema ${ }^{3}$ \\ 1, 2, 3 Jurusan Kebidanan Politeknik Kesehatan Kemenkes Manado \\ Email : Atikpurwandari75@gmail.com
}

\begin{abstract}
ABSTRAK
Latar Belakang: Pada tahun 2017 terdapat 961 (100\%) ibu hamil dan 154 (16\%) diantaranya mengalami anemia, sedangkan pada tahun 2018 terdapat 179 ibu hamil dan yang mengalami anemia $26(14,5 \%)$ ibu hamil. Pada bulan Januari-Februari 2019 terdapat 314 ibu hamil dan yang mengalami anemia yaitu sebanyak 30 ibu hamil (22,3\%). Data menujukkan ada peningkatan kasus anemia ibu hamil di Puskesmas Tuminting.

Tujuan: Mengetahui Perbedaan Pemanfaatan Jambu Biji Merah dan Pisang Ambon Terhadap Peningkatan Kadar Haemoglobin Ibu hamil di Puskesmas Tuminting Kota Manado.

Metode: Metode penelitian yang di gunakan adalah Quasi Experiment dengan rancangan pretest dan posttest control group design. Ibu hamil yang dijadikan sebagai sampel yaitu 22 orang diperoleh dengan teknik purposive sampling. Instrumen yang digunakan untuk pengumpulan data terdiri dari lembar observasi pemberian jus jambu biji merah dan pisang ambon, lembar observasi kadar haemoglobin dan alat pemeriksaan haemoglobin. Data kemudian di analisis dengan Independent Sampel T-test.
\end{abstract}

Hasil Penelitian: Menggunakan Uji Paired Sampel T-test nilai mean pada kelompok perlakuan pretest 9,1 dan posttets 9,5dan pada kelompok kontrol pretest 8,7 dan posttest 8,9 . Nilai p- Value= $0,001<0,05$

Kesimpulan: Ada pengaruh perbedaan pemanfaatan jambu biji merah dan pisang ambon terhadap peningkatan kadar haemoglobin ibu hamil di puskesmas Tuminting kota Manado.

Kata Kunci: Kadar Haemoglobin, Jambu Biji Merah, Pisang Ambon

\section{ABSTRACT}

Background: In 2017 there were 961 (100\%) pregnant women and $154(16 \%)$ of them had anemia, while in 2018 there were 179 pregnant women and 26 (14.5\%) pregnant women who had anemia. In January-February 2019, there were 314 pregnant women and 30 pregnant women who experienced anemia $(22.3 \%)$. The data shows that there is an increase in anemia cases of pregnant women at the Tuminting Health Center.

Objective: Knowing the Difference in the Use of Red Guava and Ambon Banana on the Increased Hemoglobin Levels of Pregnant Women at the Tuminting Health Center, Manado City.

Methods: The research method used was a Quasi Experiment with a pretest and posttest control group design. 22 pregnant women were taken as the sample by purposive sampling technique. The instruments used for data collection consisted of an observation sheet for giving red guava and Ambon banana juice, an observation sheet for hemoglobin levels and a hemoglobin check tool. The data were analyzed using the Independent Sample T-test.

Results: Using Paired Samples T-test, thevalue mean in thetreatment group was pretest 9.1 and posttets 9.5 and in the control group pretest 8.7 and posttest 8.9. P-value $=0.001<0.05$.

Conclusion: There is an effect of differences in the use of red guava and Ambon banana on the increase in hemoglobin levels of pregnant women at the Tuminting Health Center, Manado city.

\section{Key Words : Hemoglobin levels, Red Guava, Ambon Banana}

Volume 7 Nomor 1. Juli-Desember 2019 


\section{PENDAHULUAN}

Haemoglobin (sel darah merah) yang disingkat dengan $\mathrm{Hb}$ adalah metalloprotein atau protein yang mengandung zat besi dalam darah merah yang berfungsi mengangkut oksigen dari paru-paru ke seluruh tubuh. Haemoglobin juga memainkan peran penting dalam menjaga bentuk sel darah merah. Kadar Haemoglobin yang rendah bisa mengakibatkan anemia. Dikatakan anemia pada keadaan $\mathrm{Hb}$ dibawah 11 gr\%, anemia ringan 9-10 gr\%, anemia berat yaitu $\mathrm{Hb}$ di bawah 7 gr\%. ${ }^{(1)}$

Kekurangan haemoglobin dalam darah menimbulkan anemia. Anemia ibu hamil merupakan permasalahan nasional yang mencerminkan nilai kesejahteraan sosial ekonomi masyarakat dengan indicator Angka Kematian Ibu. Hasil Survey Demografi Kesehatan Indonesia (SDKI) tahun 2015 menunjukkan AKI di Indonesia sebesar 305/100.000 kelahiran hidup. ${ }^{(2)}$

Menurut data Dinas Kesehatan Provinsi Sulawesi Utara tahun 2016, angka kematian ibu 54 kasus dengan penyebab kematian. ${ }^{(2)}$ Anemia karena kurangnya zat besi adalah masalah utama yang terjadi pada ibu hamil dan merupakan salah satu penyebab utama kematian ibu hamil dan merupakan salah satu penyebab utama kematian ibu saat melahirkan. Penyebab dari anemia pada kehamilan yaitu: karena kekurangan asupan zat besi, adanya peningkatan kebutuhan fisiologis, adanya kebutuhan yang berlebihan, malabsorsi, kehilangan darah yang banyak (Persalinan yang lalu, perdarahan akibat infeksi kronis misalnya cacingan). Anemia pada ibu hamil sangat berbahaya karena dapat menyebabkan abortus, kehamilan premature, molahidatidosa, hyperemesis gravidarum, perdarahan antepartum, dan KPD (Ketuban Pecah Dini). ${ }^{(3)}$

Menurut Word Health Organization (WHO) kejadian anemia pada ibu hamil pada tahun 2011 berkisar 60\% dengan menetapkan $\mathrm{Hb} 11$ gr\% sebagai dasarnya (Sopianah, 2016). ${ }^{(4)}$ Hasil survei awal yang dilakukan di Puskesmas Tumunting tahun 2017 terdapat 961 (100\%) ibu hamil dan $154(16 \%)$ diantaranya mengalami anemia, sedangkan pada tahun 2018 terdapat 179 ibu hamil dan yang mengalami anemia $26(14,5 \%)$ ibu hamil. Pada bulan Januari-Februari 2019 jumlah kesuluruhan ibu hamil 314 dan jumlah ibu hamil yang memasuki kehamilan trimester III berjumlah 134 (42,6\%) ibu hamil dan yang mengalami anemia yaitu sebanyak 30 ibu hamil (22,3\%). Data menunjukkan ada peningkatan kasus anemia ibu hamil ${ }^{(5)}$

Berdasarkan Hasil penelitian sebelumnya yang dilakukan olehKonsumsi Jambu Biji (Psidium Guajava. L) Terhadap Perubahan Kadar Haemoglobin Ibu Hamil Anemia Yang Mendapatkan Sumplentasi Tablet Fe pada kelompok perlakuan yang mnegkonsumsi suplemen tablet Fe sesudah konsumsi jambu biji mengalami peningkatan $1.56 \mathrm{gr} / \mathrm{dl} /$ hari $^{(6)}$.

Berdasarkan Hasil Penelitian Sebelumnya yang dilakukan oleh Sophianah dkk (2016) konsumsi tablet Fe dengan Jambu Biji dibandingkan Konsumsi tablet $\mathrm{Fe}$ dengan Pisang Terhadap Peningkatan Kadar Haemoglobin Ibu Hamil. Menurut 
penelitian diketahui ada peningkatan kadar haemoglobin untuk Tablet $\mathrm{Fe}$ dengan Jambu Biji terjadi peningkatan ${ }^{(4)}$

\section{METODE}

Metode penelitian yang di gunakan adalah Quasi Experiment dengan rancanganpretest dan posttest control group design. Penelitian ini dilaksanakan di Puskesmas Tuminting Kota Manado, Populasi berjumlah 30 responden. Sampel pada penelitian ini adalah 22 responden. Teknik pengambilan sampel dalam penelitian ini adalah nonprobabilitysampling dengan metode purposive sampling. Rumus besar sampel yang digunakan adalah rumus besar sampel untuk uji dua mean independen. Dimana dibagi menjadi dua kelompok yaitu kelompok Perlakuan dan kontrol diamana kelompok perlakuan yaitu jambu biji merah dengan 11 responden dan kelompok kontrol yaitu pisang ambon dengan 11 responden. Teknik pengumpulan data dengan menggunakan lembar observasi dan alat pemeriksaan kadar haemoglobin. Analisis data yang digunakan adalah analisis univariat dan bivariat menggunakan uji statistik Uji Paired sampel t-test

HASIL

\section{Analisis Univariat}

\section{Gambaran Umum Responden}

Tabel 1. Distribusi Responden Berdasarkan Umur, Pendidikan dan Paritas

\begin{tabular}{ccccc}
\hline & \multicolumn{2}{c}{ Intervensi } & \multicolumn{2}{c}{ Kontrol } \\
\cline { 2 - 5 } Kategori : Beresiko & $\mathrm{n}$ & $\%$ & $\mathrm{n}$ & $\%$ \\
Tidak Beresiko & 0 & 0 & 8 & 27 \\
Pendidikan : SD & 11 & 0 & 4 & 73 \\
SMP & 0 & 27 & 5 & 36 \\
SMA & 3 & 73 & 2 & 46 \\
Paritas : Primigravida & 8 & 45 & 4 & 36 \\
Multigravida & 5 & 18 & 7 & 46 \\
Gande Multipara & 2 & 0 & 1 & 18 \\
\hline
\end{tabular}

Tabel 1 menunjukkan Usia beresiko $(<20$ atau $>35$ tahun) serta tidak beresiko (20-35 tahun). Hasil sebagian menunjukan yang beresiko (27\%), dan tidak beresiko (73\%). Pendidikan responden menunjukkan bahwa sebagian besar responden pada kelompok intervensi memiliki pendidikan SMA/SMK (73\%) danpada kelompok kontrol (46\%), sementara Paritas menunjukkan bahwa sebagian besar responden pada kelompok intervensi pada primigravida (45 \%), pada kelompok kontrol (36\%). Grandemultipara yang terbanyak yaitu multigravida 
Tabel 2. Distribusi berdasarkan kadar haemoglobinPre-test dan Post Test

\begin{tabular}{llccccccc}
\hline \multicolumn{1}{c}{ Kadar } & \multicolumn{4}{c}{ Pre Test } & \multicolumn{3}{c}{ Post Test } \\
\cline { 2 - 10 } Haemoglobin & \multicolumn{2}{c}{ Intervensi } & \multicolumn{2}{c}{ Kontrol } & \multicolumn{2}{c}{ Intervensi } & \multicolumn{2}{c}{ Kontrol } \\
& $\mathrm{n}$ & $\%$ & $\mathrm{n}$ & $\%$ & $\mathrm{n}$ & $\%$ & $\mathrm{n}$ & $\%$ \\
Tidak Anemia & 0 & 0 & 0 & 0 & 0 & 0 & 0 & 0 \\
Anemia Ringan & 8 & 73 & 5 & 46 & 8 & 73 & 6 & 55 \\
Anemia Sedang & 2 & 18 & 5 & 45 & 3 & 27 & 5 & 45 \\
Anemia Berat & 1 & 9 & 1 & 9 & 0 & 0 & 0 & 0 \\
\hline
\end{tabular}

Berdasarkan tabel 2. Menunjukkan bahwa kadar haemoglobin awal (pre-test) sebagian besar responden pada kelompok intervensi mengalami anemia Ringan dengan kadar haemoglobin 9-10 gr/dl dan pada kelompok kontrol sama besarnya mengalami anemia Ringan dan Sedang. Kadar haemoglobin akhir
(Post-test) kelompok intervensi terletak pada 9-10 gr/dl dan pada kelompok kontrol terletak pada $9-10 \mathrm{gr} / \mathrm{dL}$

\section{Analisis Bivariat}

Tabel 3.Hasil Uji Paired sampel statistic

\begin{tabular}{|c|c|c|c|c|c|c|}
\hline \multicolumn{7}{|c|}{ Kelompok } \\
\hline \multirow{3}{*}{$\begin{array}{l}\text { Kadar } \\
\text { Haemoglobin } \\
\text { Pre-test }\end{array}$} & \multicolumn{3}{|c|}{ Intervensi } & \multicolumn{3}{|c|}{ Kontrol } \\
\hline & Mean & $\begin{array}{l}\text { Standar } \\
\text { Deviasi }\end{array}$ & $\mathrm{P}$ & Mean & $\begin{array}{l}\text { Standar } \\
\text { Deviasi }\end{array}$ & $\mathrm{P}$ \\
\hline & 9,1 & 0,989 & \multirow{2}{*}{0,000} & 8,7 & 0,797 & \multirow{2}{*}{0,000} \\
\hline Post-test & 9,5 & 0,987 & & 8,9 & 0,772 & \\
\hline
\end{tabular}

Tabel 2 menunjukkan Rerata kenaikan kadar haemoglobin pada kelompok intervensi sebesar 0,47 $\mathrm{gr} / \mathrm{dl}$ dan kelompok kontrol $0,20 \mathrm{gr} / \mathrm{dl}$ hal ini menunjukkan adanya pengaruh kadar haemoglobin setelah mengkonsumsi Jambu biji merah dengan pisang. Hal ini dapat dikatakan bahwa yang bermakna terdapat kenaikan haemoglobin yang signifikan pada kelompok intervensi yaitu jambu biji merah dan kelompok kontrol yaitu pisang ambon. Diketahui nilai mean pada kelompok intervensi lebih besar dibandingakn pada kelompok kontrol. Hal ini dapat disimpulkan bahwa ada pengaruh perbedaan pemanfaatan jambu biji merah dan pisang ambon terhadap peningkatan kdar haemoglobin ibu hamil di Puskesmas Tuminting Kota Manado.

\section{PEMBAHASAN}

\section{Gambaran Karakteristik Responden}

Faktor usia merupakan faktor risiko kejadian anemia pada ibu hamil. Usia seorang ibu berkaitan dengan alat-alat reproduksi wanita. Umur reproduksi yang sehat dan aman adalah umur 20-35 tahun. Kehamilan di usia $<20$ tahun dan di diatas 35 tahun dapat menyebabkan anemia karena pada usia $<20$ tahun secara biologis belum optimal emosinya cenderung labil, 
mentalnya belum matang sehingga mudah mengalami keguncangan yang mengakibatkan kurangnya perhatian terhadap pemenuhan kebutuhan zat-zat gizi selama kehamilan, sedangkan pada usia >35 tahun terkait dengan kemunduran dan penururnan daya tahan tubuh serta berbabgai penyakit yang sering menimpa diusia ini (6). Responden dalam penelitian ini menunjukkan keberagaman yang luas dalam rentang usia. Responden termuda berusia 18 tahun dan yang paling tua berusia 44 tahun.

Pendidikan merupakan salah satu faktor yang bisa menentukan peningkatan tingkat pengetahuan responden. Hubungan yang signifikan antara pendidikan dengan kejadian anemia pada ibu hamil karena tinfkat pendidikan seorang ibu akan mempengaruhi kesadaran untuk berperilaku hidup sehat dan membentuk pola pikir yang baik ${ }^{(8)}$. Tingkat pendidikan sangat mempengaruhi bagaimana seorang untuk bertindak dan mencari penyebab serta solusi dalam hidupnya. Orang yang berpendidikan tinggi akan bertindak lebih rasional, oleh karena itu orang yang berpendidikan akan lebih mudah menerima gagasan baru. Demikian halnya dengan ibu yang berpendidikan tinggi akan memeriksakan kehamilannya secara teratur demi menjaga keadaan kesehatan dirinya dan anak dalam kandungannya $^{(9)}$. Apabila dilihat dari komposisi pendidikan, responden dengan status pendidikan tinggi (tamatan SMA) sebanyak 10 orang
(46\%) dan responden berstatus pendidikan (tamatan SMP) sebanyak 8 orang (36\%) dan responden yang berpendidikan (tamatan SD) sebnyak 4 orang (18\%). Tingkat pendidikan tidak menunjukan suatu pola sehingga pendidikan tidak mempunyai pengaruh terhadap kenaikan kadar haemoglobin.

Jenis Pekerjaan dalam sektor informal dengan beban kerja fisik yang relative lebih berat, menyebabkan seseorang mengelurkan banyak keringat. Hal ini mengakibatkan peningkatan pengeluaran zat besi bersama keringat. Wanita hamil yang melakukan beban kerja berat memerlukan banyak sekali makanan untuk kondisi kesehatan tubuhnya maupun untuk kebutuhan energinya, sehingga zat-zat gizi yang dibutuhkan harus tercukupi. Sedangkan dari beban pekerjaan diketahui responden dengan pekerjaan IRT sebanyak 22 orang (100\%). Pekerjaan tidak mempunyai pengaruh terhadap kadar haemoglobin.

Paritas merupakan salah satu penyebab tidak langsung yang mempengaruhi kejadian anemia. Seorang ibu yang sering melahirkan mempunyai risiko mengalami anemia pada kehamilan berikutnya apabila tidak memperhatikan anemia ${ }^{(10)}$ Anemia dipengaruhi oleh kehamilan dan persakinan yang sering, semakin sering seorang wanita mengakami kehamilan dan persalinan akan semakin banyak kehilangan zat besi dan semakin anemis ${ }^{(11)}$. Responden pada penelitian ini 
sebagian besar masuk dalam kategori tidak beresiko. Paritas memiliki peran penting sebagai faktor resiko dalam kemungkinan terjadinya anemia dalam kehamilan. Paritas lebih dari 3 merupakan faktor terjadi anemia disebabkan karena terlalu sering hamil dapat menguras cadangan zat besi tubuh ibu. Jumlah anak yang dilahirkan wanita selama hidupnya sangat mempegaruhi kesehatanya ${ }^{(11)}$. Data yang di dapatkan bahwa sebagian responden berstatus multigravida atau ibu yang melahirkan lebih dari satu kali yaitu sebanyak 15 orang (68\%) dan responden yang bertatus grande multipara sebayak 1 orang $(6 \%)$

Kunjungan Antenatal diharapkan menjadi salah satu faktor yang dapat mengurangi resiko terjadinya anemia. Kunjungan Antenatal Care (ANC) Antenatal Care adalah pengawasan sebelum persalinan terutama pada pertumbuhan dan perkembangan janin dalam rahim. Kasus anemia defisiensi gizi umumnya selalu disertai dengan mal nutrisi infestasiparasit, semua ini berpangkal pada keengganan ibu untuk menjalani pengawasan antenatal $^{(13)}$.

Salah satu tujuan pemeriksaan ANC adalah mengenali dan menangani penyakit yang menyertai kehamilan. Cakupan pelayanan antenatal dapat dipantau melalui kunjungan ibu hamil. Pelayanan paling sedikit 4 kali kunjungan dengan distribusi sekali pada triwulan pertama (K1), sekali pada triwulan kedua (K2), dan dua kali pada triwulan ketiga
(K4). Jadi total kunjungan ANC adalah 4 kali kunjungan. Melalui pemeriksaan ANC ibu dapat memperoleh penyuluhan kesehatan yang berhubungan dengan gizi dan makanan, serta mendapatkan tablet tambah darah dari petugas kesehatan dimana konsumsi tablet tambah darah dari petugas kesehatan akan memperkaecil terjadiya anemia dalam kehamilan $^{(14)}$. Apabila dilihat dari kunjungan ANC untuk kunjungan ANC yang paling banyak yaitu 6 kali kunjungan yaitu 11 orang (50\%).

2. Analisis Variabel

Pengaruh Pemanfaatan Perbedaan Jambu Biji dan Pisang Ambon. Pada penelitian ini terdapat $22 \mathrm{ibu}$ hamil trimester III dengan kadar haemoglobin $<11 \mathrm{gr} / \mathrm{dl}$ yang berada di Puskesmas Tuminting Kota Manado. Dari 22 sampel tersebut, 11 sampel pada kelompok intervensi dan 11 sampel pada kelompok kontrol. Kedua sampel akan mendaptkan perlakuan selama 7 hari. Kelompok intervensi diminta untuk mengkonsumsi jambu buji merah sebanyak $200 \mathrm{ml}$ yang diminum pada malam hari bersamaan dengan tablet Fe. Sedangkan kelompok kontrol diminta untuk mengkonsumsi pisang ambon $320 \mathrm{gr}$, pagi,siang dan malam dan pada malam hari bersamaan dengan tablet Fe.

Tahap pertama dalam penelitian ini yaitu pre-test dengan melakukan pemeriksaan kadar haemoglobin ibu hamil trimester III dan hasil pre-test dilakukan pada 22 ibu hamil ditemukan kadar haemoglobin <11 gr/dl Pada tahap kedua dalam 
penelitian ini adalah responden dibagi menjadi dua kelompok, yaitu 11 kelompok intervensi dan 11 kelompok kontrol. Kemudian 11 kelompok intervensi diberikan Jus Jambu Biji Merah dan 11 kelompok kontrol diberikan pisang ambon.

Kemudian peneliti melakukan perlakuan pada 11 kelompok intervensi dengan memberikan jus jambu biji sebanyak $200 \mathrm{ml}$ didistribusikan pda malam hari bersamaan dengan tablet $\mathrm{Fe}$ dan pada 11 kelompok kontrol dengan memberikan 320 gr pisang ambon yang diditribusikan pada pagi,siang dan malam dan pada malam hari dikonsumsi bersamaan dengan tablet Fe.

Pada tahap ketiga hasil yang di dapatkan dari penelitian selama 7 hari semua semua responden melakukan pretest dengan melakukan pemeriksaan kadar haemoglobin didapatkan kadar haemoglobin sebelum diberikan intervensi $<10,2$ gr/dl dan setelah diberikan intervensi sebesar 10,6 gr/dl. Kadar haemoglobinpre-test pada kelompok kontrol 9,7gr/dl dan post-test 9,8 gr/dl. Hal ini adanya pengaruh Perbedaan Pemanfaatan Jambu biji Merah dengan Pisang Ambon.

Berdasarkan hasil uji statistic dengan uji paired sample T-test dengan nilai kemaknaan 0,05 ditemukan bahwa $\mathrm{P}=$ $0,000<0,005$. Pada kelompok intervensi dan $\mathrm{P}=0,000$ pada kelompok kontrol $\mathrm{P}=0,000$. Sehingga dapat dinyatakan bahwa kelompok intervensi dan kelompok berarti hipotesis diterima. Dengan demikian disimpulkan bahwa Ha diterima, artinya pengaruh Perbedaan Pemanfaatan Jambu Biji Merah dengan Pisang Ambon
Terhadap Peningkatan Kadar Haemoglobin Pada Ibu Hamil di Puskesmas Tuminting Kota Manado.

Jadi jambu biji merah dengan pisang ambon sangat baik dikonsumsi untuk meningkatkan kadar haemoglobin ibu hamil untuk mencegah terjadinya anemia dan mengurangi resiko akan terjadinya perdarahan pada ibu hamil ketika bersalin.

Berdasarkan Hasil penelitian sebelumnya, konsumsi Jambu Biji (Psidium Guajava. L) Terhadap Perubahan Kadar Haemoglobin Ibu Hamil Anemia Yang Mnedapatkan Sumplentasi Tablet Fepada kelompok perlakuan yang mnegkonsumsi suplemen tablet Fe sesudah konsumsi jambu biji mengalami peningkatan $1.56 \mathrm{gr} / \mathrm{dl}^{(6)}$.

Berdasarkan Hasil Penelitian sebelumnya yang dilakukan oleh Dewi (2017). Pengaruh Konsumsi Buah Pisang Ambon Terhadap Anemia Pada Ibu Hamil Trimester I. menurut peneliti diketahui bahwa setelah mengkonsumsi pisang ambon selama 1 minggu terjadi peningkatan $\mathrm{Hb}$. Penelitian dilakukan selama 7 hari respoden diberikan pisang ambon sebanyak 320 gr setiap hari. Tablet $\mathrm{Fe}$ dengan pisang mengalami kenaikan sebesar 0,29 gr\%. Hasil Penelitian Rahma dkk, (2016) terdapat pengaruh sebelum dan sesudah pemberian buah pisang ambon terhadap peningkatan kadar haemoglobin pada ibu hamil TM I. Penelitian ini disarankan untuk ibu hamil TM I agar mengkonsumsi buah pisang ambon karena sudah terbukti bahwa ada peningkatan kadar haemoglobin ${ }^{16}$.

Berdasarkan Hasil Penelitian Sebelumnya yang dilakukan oleh Sophianah (2016) ${ }^{(4)}$. Konsumsi Tablet Fe 
dengan Jambu Biji dibandingkan Konsumsi Tablet Fe dengan Pisang Terhadap Peningkatan Kadar Haemoglobin Ibu Hamil. Menurut penelitian diketahui ada peningkatan kadar haemoglobin untuk Tablet $\mathrm{Fe}$ dengan Jambu Biji terjadi peningkatan yaitu 0,42 dan Tablet Fe dengan Pisang yaitu 0,29.

Ibu hamil Rutin melakukan pemeriksaan kehamilan dan cek kadar haemoglobin adtah minimal sebulan sekali

\section{DAFTAR PUSTAKA}

1. Solang, S, D, Makalew, L, Oktaviani, I (2016). ProfilHaemoglobin Ibu Hamil Dilihat Dari Beberapa Faktor Pendukung. Poltekkes Kemenkes Manado. https://media.neliti.com diakses 24 Maret 2019

2. Dinas Kesehatan Kota Manado (2017). Profil Kesehatan Kota Manado 2017. http://www.depkes.go.id diakses 17 Januari 2019

3. Dewi, R, K (2017). Pengaruh Konsumsi Pisang Ambon Terhadap Anemia Pada Ibu Hamil Trimester I di Wilayah Kerja Puskesmas Balowerti. Fakultas Ilmu Kesehatan Universitas Kediri. https://studylibid.com di akses pada tanggal 20 Maret 2019

4. Sopianah, Y, Mintrasih, W, Anggini, T, S (2016). Konsumsi Tablet Fe denganJambu Biji di Bandingkan Konsumsi Tablet Fe dengan Pisang Terhadap Peningkatan Kadar Hemoglobin Ibu Hamil di Wilayah Kerja PuskesmasBacem Kabupaten Blitar. Poltekkes Kemenkes Tasikmalaya. http://jurnal.ibijabar.org di akses tanggal 18 Januari 2019

5. Astrina, W (2017). Kejadian Pada Ibu Hamil Yang Ditiinjau DariParitas dan Umur. Program Studi DIII Kebidanan STIKES AlMa'arif Baturaja

6. Sri Rahayu. (2014). Pengaruh Konsumsi Jambu Biji (Psidium Guajava.L) Terhadap Perubahan Kadar Hemoglobin Ibu Hamil Anemia Yang Mendapat Fe.http://eprints.undip.ac.id/43154/ diakses pada tanggal 19 Juni 2019

7. Fitriasari, I (2016). Faktor-faktor Yang Berhubugan Dengan Kejadian Anemia Pada Ibu Hamil Trimester III di Puskesmas Tegalrejo. Fakultas Aisyiyah Yogyakarta.http://digilib.unisayogya.ac.id/2724/1/NASKAH\%20PUBLIKASI INDAH\%20FITRI ASAI_1610104376_8A_DIV\%20BIDAN\%20PENDIDIK.pdf. Diakses pada tanggal 22 Juni 2019

8. Mariza, A (2016). Hubungan Pendidikan dan Sosial Ekonomi Dengan KejadianAnemia Pada Ibu Hamil Di BPS $\mathrm{T}$ Yohan Way Halim Bandar Lampung.malahayati.ac.id/wpcontent/uploads/2016/07/Jurnal-Ana-Mariza.pd di aksespada tanggal 11 Juli 2019

9. Walyani, E, S, Purwoastuti, E (2015). Ilmu Obstetri dan Ginekologi Sosial Bagi Kebidanan. Yogyakarta: Paper Plane

10.Ramadani, M (2012). Penyebab Kejadian Anemia Ibu Hamil di Puskesmas Seberang Padang Kota Padang. http://jurnal.fkm.unand.ac.id/index.php/jkma/article/view/90/96. Diakses pada tanggal 11 Juli 2019

11.Fikriana, U (2014). Faktor-Faktor Mempengaruhi Kejadian Anemia Pada Ibu Hamil di Puskesmas Kasihan II Bantul. http://digilib.unisayogya.ac.id/1272/. Diakses pada tanggal 11 Juli 2019

12.Arisman, 2004. Gizi Dalam Daur Kehidupan.Anemia Defisiensi Zat Besi. Jakarta : Penerbit Buku Kedokteran ECG.

Volume 7 Nomor 1. Juli - Desember 2019 
13.Nurhidayati, D.R. 2013. Analisis Faktor Penyebab Terjadinya Anemia Pada Ibu Hamil Diwilayah Kerja Puskesmas Tawangsari Kabupaten Sukoharjo.

14.Sumiyarsi, I (2018). Faktor-Faktor Yang Mempengaruhi Hemoglobin Ibu HamilTrimester III. https://jurnal.uns.ac.id/placentum/article/view/22836 diakses pada tanggal 11 Juli 2019

15.Rahma Kusuma Dewi, Pengaruh Konsumsi Buah Pisang Ambon terhadap Anemia Pada Ibu Hamil Trimester I Di Wilayah Kerja PuskesmasBalowerti Tahun 2016 